\title{
Strategies on Literary Reading in College English Teaching Based on Aesthetic Reception Theory
}

\author{
$\mathrm{Na} \mathrm{Li}$ \\ School of Foreign Language \\ Northeast Dianli University \\ Jilin, China \\ e-mail: lena1981_2000@126.com
}

\begin{abstract}
The aesthetic reception stresses on the reader's response in the process of appreciation and understanding in literary works. The aesthetic experience based on individual growing and teaching experience is advocated in literary reading class. The interaction is achieved effectively between reader's expectation and calling structure in literary works, between explicit knowledge and tactic knowledge in students' mental space, and between the lead-in of teachers and the personal understandings of students. This theory reflects the essence of reading behavior and reading. This paper is aimed to study the strategies on literary reading in college English teaching based on aesthetic reception theory and improve the reading ability. From the perspective of learning results, this study is also beneficial for the development of students in rich imagination, independent thinking and critical judgment during college period.
\end{abstract}

Keywords-aesthetic reception theory; reading strategy; the expectation of readers; implied readers

\section{INTRODUCTION}

It is considered as a century of self-reflection or introspection for the twentieth century [1]. The research perspective is becoming to focus on the subjectivity in many scientific fields and increasingly disconnected from the previous emphasis on objectivity. In literary field, the introduction of aesthetic reception theory brings a new method in language teaching research. The original emphasis in language teaching is shifting from words and text understanding to reader-centered appreciation based on different personal experiences.

\section{THEORATICAL BACKGROUND}

\section{A. Aesthetic Reception Theory and Literary Reading}

Aesthetic Reception Theory, Reception aesthetics or Reader-oriented criticism is considered as a transformation of interpretation in the mid-20th century. It is originated from the phenomenology of Husserl and established in the late 1960s. Hans-Robert Jauss, Wolfgang Iser and Stanley Fish are the main representatives of the research on aesthetic reception theory ${ }^{[2]}$.

Aesthetic reception theory takes the reader's response and reception as the center in the research. In the later part of last century, the concentration is changing from on the "outside" to the "inside" of a thing in many fields, which means the stress on subjectivity. This approach to textual analysis provides more weights on "negotiation" and "reaction" between the literary work and readers among the three key elements in literary work appreciation: work, reader and author. Therefore, the reader-centered reading advocates that different readers could have different understandings and appreciations on the same literary work or would vary in a wide range of understandings and appreciations towards the same literary work in different historical periods.

The subjectivity of reader-centered reading differs in growing and educational background, social status and personal taste. The appreciation on literary works is dependent on individual responses according to different time and experience. The attributions to the variation arise from two reasons according to the aesthetic reception theory, including the reader's expectation or horizon of expectations and the "implied meaning" in calling structures[3]. The appreciation on a literary work is a continual reaction or reflection from the expectations of readers and calling structures. In this case, many implied understandings and ideational activity gradually have discovered and accepted by the readers. It is can be concluded that reading becomes a process of re-creation in comprehension.

\section{B. Literature Review on Literary Reading Strategies}

Literary work is a kind of art and the reflection of author's thoughts and social life. Literary reading is different from common reading tasks appeared in various forms of newspaper, magazines or examinations. Literary reading is more connected with native-like language expressions, the realization of semantics, pragmatics and functional linguistics, and the understanding of culture in literary field.

The strategies on reading not only include the skills in prediction, glancing, skimming and reasoning, but the selected and controlled behavior in reading, such as monitoring the reading pace. In addition, the strategies on reading are enlarged to a wider scope of activating background information on the subjects. The recent research on reading strategies ranges widely, such as the perspective of psychological linguistics[4], text-taking strategies[5], discourse analysis[6], global and local coherence[7], motivational self-regulation and cognitive self-regulation [8], textual structure[9], metacognitive strategies[10] and 
strategies for attention, selection, organization, integration and monitoring[11].

\section{Situation on College Literary Reading}

Literary reading is conducted in college in the way of extensive reading. There are several problems in college literary reading in two aspects. Firstly, the provision of literary materials is limited and the monitory assessment is not sufficient for the judgment of student's performance. In particular, the way to test the comprehension on the literary materials for the students is confined to provide choices. The pattern is passive. Secondly, incidental reading and intentional reading for literary materials are not based on characteristics according to individual's preference and language acquisition ability.

\section{STRATEGIES ON LITERARY READING ON AESTHETIC RECEPTION THEORY}

\section{A. Strategies Based on Aesthetic Reception Theory}

The literary reading is considered as a way in improving reading ability for the development of second language acquisition. Literary fuzziness or uncertainty includes semantic indeterminacy, image space and calling structure. The strategy based on aesthetic reception theory is the interaction between reader, author and literary work. The strategies based on aesthetic reception theory reflect the essence of interaction.

The readers involve three kinds of readers, authentic reader and the two assuming implied readers, including contemporary reader and ideal reader. The vantage point dominates relationship between the readers and calling structure. The first step is the understanding of reader's expectation. College students with different growing and reading experiences vary in a range of difference in reader's expectation and reading ability. The literary materials should divide into three kinds according to the difficulty of original works. This step is helpful for the improvement in reading ability for classic reading; The second step is the formation of students' own image space for literary material based their own penetrations. The purpose is not to get what the writers is trying to tell the students, but to know what the students appreciate, think and form in their mental space. The readercentered aesthetic experience on literary materials is endless and cannot be substituted by teachers' instructional understanding; The third step is personal reflections and critical thinking after aesthetic experience. This step is the process in the realization of reader's expectation and calling structure. The teachers should play the lead-in role in the beginning of students' presentation on aesthetic experiences. In addition, emphasis on the afterthoughts from some penetrative quotations in literary materials is a key to launch a group discussion.

\section{B. Appreciation on Austen's Novels as an Example}

This paper takes the appreciation of Austen's Novels as example on aesthetic reception theory. Firstly, emphasis on reader-centered understanding explores the different reader's expectations in different historical background. For the works of Austen, she lived in the transitional period between the eighteenth and the nineteenth centuries, between the end of Classicism and the beginning of Romanticism[12]. The time of Jane Austen was a special period in English history because the traditional English fashion moved away and the new system for new era had not been established. According to the processes of the various appreciations when Austen's novels were published, four stages on the reception were involved because the different expectations of different readers in general overview[13]. Secondly, the interaction between author-centered and reader-centered views is helpful in developing characteristics according to the different periods of history. For example, the reception periods for Austen's novels are divided into four stages: a) The first is disparaged period. We all know that her novels were published anonymously, not only because of her gender and a desire for privacy, but because of the repression of social atmosphere. English society molded females into the image of angels within the limitation of being a moral and behaved housewife. A woman' entrance into society was regarded as the moral decay. Under such conditions, Austen's writing in her time cannot be accepted widely; b) The second period is controversial stage. Appreciation on Austen's novel was increased gradually by the controversial discussion on the weaknesses and strengths of Austen's novels. In spite of some satire from critics for her limited writing vision, there still was much recognition from critics for the greatness appeared in her rural description and mental penetration; 3) The third period is warm discussed period. By the mid-twentieth century, the comments on Jane Austen's novels were emerging with the change of historical development; 4) The fourth period is systematic period. At the end of the last century, the research on Jane Austen achieved in highest level. Many academic articles and discussion groups on Jane Austen and her novels were widely issued and discussed with the readers' increasing desire and attention on Austen's mental world. The interaction between real reader and ideal reader is achieved by the comparison of these four different periods.

Based on the above analysis on historical background, variation in understanding with different time and readers is forming. Therefore, ideational activity is conducted and students are easy to establish their own expectations both in the contemporary readers and real readers. Through the response-inviting structures, the calling structures in literary works emerge with the aesthetic experience based on the students with differences in backgrounds. For the purpose of improvements in language expression and understanding of literary works, self-reflection or afterthought on Austen's novels is carried by the way of group discussion or writing. This is a free talk on different interesting points appeared in personal reading experience.

Aesthetic reception theory has the function of recalling informational background for a reader. The combination of implicit learning and tacit learning, incidental learning and intentional learning is achieved along the process of continual understanding on literary works. 


\section{CONCLUSION}

Reading is not a process of passive reception, but a complex and positive process of psychological activity and information collection.

The aesthetic reception theory provides a new perspective in depth of understanding and appreciation of literary works from the role of readers. This way widens the ways of understanding and promotes readers interests at the same time. Strategies based on aesthetic reception in teaching instructional design keep a positive attitude in the individual subjectivity in reading activities. This kind of strategy establishes a free and open environment in class and brings benefits to the students with rich imagination and wide connection on the overall knowledge. In a long run, from the perspective of students, strategy based on aesthetic reception is helpful for the development of students' imagination and independent thinking; From the perspective of learning results, it is also helpful for student to grasp the knowledge on an enlarged scope, both horizontally and vertically.

\section{REFERENCES}

[1] Zhugang. "Western Literary Theory in Twentith Century". Beijing: Beijing University Press, 2007.

[2] Abrams, MH. "A Glossary of Literary Terms". Beijing: Foreign Language Teaching and Research Press, 2004.
[3] Iser, Wolfgang. 'The Act of Reading: A Theory of Aesthetic Response". Baltimorne \& London: The Johns Hopkins University Press,1987.

[4] De Jager, B. et al. "The Effectes of Teacher Training on New Instructional Behaviour in Reading Commprehension". Teaching and Teacher Education, 2002, pp. 832-834.

[5] Bornholt, L.J. “An Analysis of Childern's Task Strategies for a Test of Reading Comprehension". Contemporary Educational Psychology, 2002.

[6] Ikeda M, Takeuchi O. "Clarifying the Difference in Learning EFL Reading Strategies: An Analysis of Portfolios”. System, 2006.

[7] Beishuzen. "No Correlation between Inferencing Causual Relations and Text Comprehension". Learning and Translation, 1999.

[8] Sheorey R, Mokhtari K. "Difference in the Metacognitive Awareness of Reading Strategies Among Native and Non-native Readers". System, 2001.

[9] Leon J. Caarretero M. "Intervention Incomprehension and Memory Strategies: Knowledge and Use of Text Structure". Learning and Instruction, 1995.

[10] Vauras, M. et al. "Motivational Vulnerability as a Challenge for Educational Interventions". Internal Journal of Education Research, 1991.

[11] Sung Y. T. et al. "Improving Children's Reading Comprehension and Use of Strategies through Computer-based Strategy Training". Computers in Human Behaviour, 2008.

[12] Lisa Plummer Crafton. "Jane Austen and Religion: Salvation and Society in Georgian England". Christianity and Literature, 2005.

[13] Li Na. "On the Reception Process of Sense and Sensibility from the Perspective of Aesthetic Reception Theory". Journal of Educational Institute of Jilin Province, 2012 